PENELITIAN

\title{
Kadar Substansi P Serum Pada Pemberian Parasetamol Intravena Perioperatif Pada Pasien Kraniotomi
}

\section{The Effect Of Perioperative Intravenous Paracetamol On Serum Substance P Level In Craniotomy Patient}

\author{
Bondan Irtani Cahyadi $\bigotimes^{*}$, Hariyo Satoto*, Heru Dwi Jatmiko* \\ * Bagian Anestesi dan Terapi Intensif Fakultas Kedokteran Universitas Diponegoro/ RSUP Dr. Kariadi Semarang. \\ $\bowtie$ Korespondensi/ Correspondence: bondanice@gmail.com
}

\section{ABSTRACT}

Background: Pain management after craniotomy is very important, 60-84\% patient experience moderate to severe pain. Postoperative pain especially transmitted by $C$ fiber neurons involved neuropeptide Substance P (SP). Postoperative opioid analgesia gives some adverse effect, such as allergy, gastrointestinal effect, nausea. vomiting, hypotension, sedation, repiratory depression and urinary retention. Paracetamol has opioid sparing effect that may reduce the need of opioid analgesia, and also inhibits SP mediated hyperalgesia.

Objective: To study the effect of perioperative intravenous paracetamol on SP level in post craniotomy patient

Methods: Forty subject aged 18 - 45 years underwent elective craniotomy intracerebral tumour resection who have ASA physical status I-II, divided into 2 groups. P group received $1000 \mathrm{mg}$ intravenous paracetamol every 6 hours during 24 hours postoperative, $K$ group received placebo. Postoperative analgesia using morphine syringe pump $0,01 \mathrm{mg} / \mathrm{Kg} / \mathrm{hour}$ titration to VAS. SP serum levels were examined with Cusabio substance Elisa kit ELx 800 before and 12 hours after surgery. Visual Analog Scale noted in 1, 6, 12, and 24 hours postoperative. Total amount of morphine given, nausea and vomiting was noted.

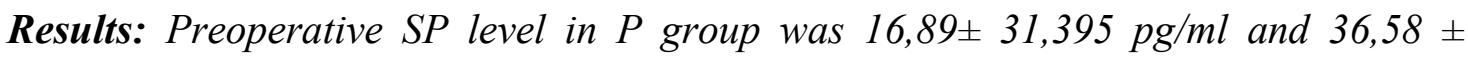
$46,960 \mathrm{pg} / \mathrm{ml}$ postoperatively. Preoperative SP Level in K group was 9,58 $\pm 10,656 \mathrm{pg} /$ $\mathrm{ml}$ and 26,09 $\pm 22,506 \mathrm{pg} / \mathrm{ml}$ postoperatively. SP level elevation in $P$ group and $K$

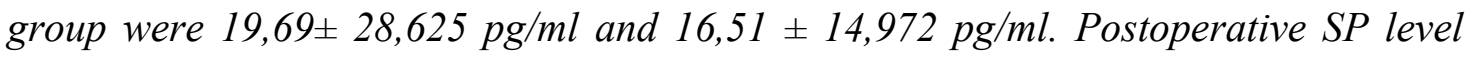
and the elevation were not significantly different between two groups ( $p=0,793$ and $p=0,540), \quad V A S$ and total amount of morphine given was significantly different $(p<0,05)$.

Conclusion: Perioperative intravenous paracetamol reduced morphine consumption and gave better VAS in post craniotomy patient, but did not affected postoperative SP level.

Keywords :Intravenous paracetamol, Substance P, VAS, Morphine, Craniotomy 


\section{ABSTRAK}

Latar belakang: Manajemen nyeri pasca kraniotomi sangat penting karena 60-84\% pasien pasca kraniotomi merasakan nyeri sedang hingga berat. Rasa nyeri ini ditransmisikan olehserabutsaraf C yang melibatkan neuropeptida substansi P (SP). Pemberian analgetik golongan opioid memiliki efek samping seperti alergi, gangguan gastrointestinal, mual, muntah, hipotensi, depresi nafas maupun retensi urin. Paracetamol memiliki efek yang mengurangi kebutuhan analgesia opioid, dan menghambat hiperalgesia yang dimediasi oleh SP.

Tujuan: Mengetahui efek pemberian parasetamol intravena perioperatif terhadap kadar SP serum pasca kraniotomi.

Metode: Empat puluh responden berusia 18-45 tahun akan menjalani kraniotomi reseksi tumor intraserebral elektif, ASA I-II, dibagi menjadi 2 kelompok. Kelompok $P$ diberikan paracetamol $1000 \mathrm{mg}$ intravena per 6 jam selama 24 jam pasca operasi, kelompok $K$ mendapat plasebo. Analgetik pasca operasi menggunakan morfin syringe pump 0,01 mg/kg/jam titrasi sesuai VAS. Level SP serum diperiksa menggunakan Cusabio SP ELISA kit sebelum operasi dan 12 jam setelah operasi. VAS dinilai pada jam 1, 6, 12, dan 24 jam pasca operasi. Jumlah total pemakaian morfin dalam 24 jam dan efek mual muntah dicatat.

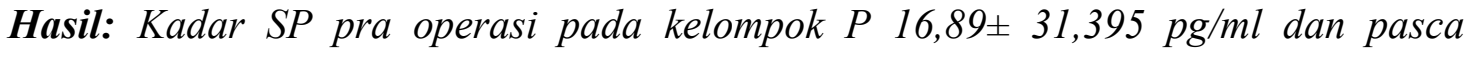
operasi 36,58 $\pm 46,960 \mathrm{pg} / \mathrm{ml}$. Level SP pra operasi kelompok K 9,58 $\pm 10,656 \mathrm{pg} / \mathrm{ml}$ dan pasca operasi 26,09 $\pm 22,506 \mathrm{pg} / \mathrm{ml}$. Peningkatan kadar SP pasca operasi

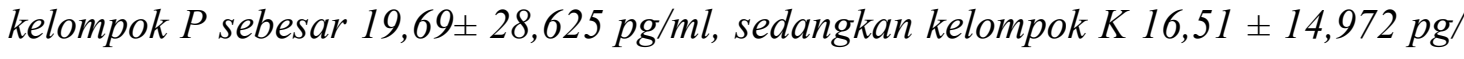
ml. Tidak terdapat perbedaan bermakna antara kadar SP dan peningkatannya pada kedua kelompok penelitian ( $p=0,793$ dan $p=0,540)$, sedangkan nilai VAS dan jumlah morfin yang diberikan berbeda bermakna $(p<0,05)$.

Simpulan: Pemberian parasetamol intravena perioperatif pada pasien kraniotomi mengurangi kebutuhan morfin dan nilai VAS lebih baik, namun tidak mempengaruhi kadar SP pasca operasi.

Kata Kunci : Paracetamol intravena, Substansi P, VAS, Morfin, Kraniotomi

\section{PENDAHULUAN}

Sekitar 60-84\% pasien pasca kraniotomi mengalami nyeri moderat hingga berat. ${ }^{1,2}$ Nyeri pasca kraniotomi paling sering terjadi dalam 48 jam setelah operasi, terutama setelah 12 jam pasca operasi. Manajemen nyeri pada pasien pasca kraniotomi masih belum banyak diteliti. Disamping itu, panduan klinis mengenai manajemen nyeri pasca kraniotomi di rumah sakit juga belum didukung dengan bukti klinis hasil penelitian yang adekuat.

Ada banyak mediator yang 
berperan dalam proses terjadinya nyeri, seperti histamin, prostaglandin, bradikinin dan substansi P. Substansi P merupakan mediator nyeri yang paling dominan. ${ }^{3}$ Menurut Dunbar et al nyeri pada pasien pasca kraniotomi justru membutuhkan lebih sedikit analgetik dibanding dengan tindakan pembedahan mayor lainnya. ${ }^{4}$ Penggunaan opioid pasca operasi memiliki beberapa efek samping yang merugikan, diantaranya alergi, efek gastrointestinal, mual muntah, hipotensi, sedasi, depresi respirasi dan retensi urin. ${ }^{5}$

Parasetamol merupakan obat anti-inflamasi non steroid yang memiliki efek anti-piretik dan analgetik.Efek analgetik parasetamol karena perannya dalam menghambat enzim siklooksigenase baik di sentral maupun perifer. Mekanisme lain melalui jalur nitric oxide, dimana parasetamol menghambat hiperalgesia yang dimediasi substansi P. ${ }^{6}$ Penelitian oleh Maund menunjukkan bahwa parasetamol memiliki efek opioid sparing sehingga mengurangi kebutuhan opioid untuk analgetik pasca operasi. $^{7}$

Potensi parasetamol intravena sebagai analgesia preemptif pada pasien kraniotomi menarik untuk diteliti. Perlu diketahui efeknya sebagai antinosisepsi dengan cara mengukur kadar substansi $\mathrm{P}$ dalam serum dan hubungannya dengan skor nyeri menggunakan Visual Analog Scale (VAS).

\section{METODE}

Penelitian ini termasuk jenis uji klinis acak tersamar ganda. Kriteria inklusi: dewasa usia $18-45$ tahun, menjalani operasi kraniotomi reseksi tumor intraserebral elektif , Body Mass Index (BMI) normal (18.5 - $\left.25 \mathrm{~kg} / \mathrm{m}^{2}\right)$, status Fisik ASA I-II, mampu komunikasi secara verbal, mampu menggunakan Visual Analog Scale (VAS) dan durasi operasi kurang dari 360 menit. Kriteria eksklusi: alergi parasetamol, morfin atau agen anestesi lain yang digunakan dalam penelitian, konsumsi parasetamol, NSAID atau analgesik lain secara rutin, gangguan hepar (kadar transaminase $>1,5 \mathrm{x}$ kadar normal atas) atau insufisiensi ginjal (kreatinin $>2 \mathrm{mg} / \mathrm{dL}$ ), riwayat atau suspek konsumsi alkohol atau penyalahgunaan obat, hamil atau menyusui, keterbatasan komunikasi karena gangguan kesadaran atau kognitif dan hipertensi tidak terkontrol.

Sampel sebanyak 40 subjek yang memenuhi kriteria inklusi dan eksklusi, dibagi dalam dua kelompok: kelompok $\mathrm{K}$ mendapat infus $\mathrm{NaCl} \quad 0,9 \% 100 \mathrm{cc}$ tiap 6 jam selama 24 jam, kelompok $P$ mendapat infus parasetamol $1000 \mathrm{mg}$ (100 cc) tiap 6 jam selama 24 jam. Kedua kelompok mendapat analgetik morfin syring pump $0,01 \mathrm{mg} / \mathrm{kgBB} / \mathrm{jam}$, dosisnya dinaikkan bila nilai VAS $>3$. Kebutuhan analgetik opioid pasca operasi dan komplikasi pasca operasi seperti mual, muntah dan sedasi dicatat. Pemberian analgetik OAINS lain tidak diperbolehkan. Sampel darah untuk 
pemeriksaan substansi $\mathrm{P}$ diambil sebelum operasi dan 12 jam setelah operasi.

\section{HASIL}

Didapatkan $\quad 40 \quad$ subjek penelitian masuk dalam kriteria inklusi. 2 orang subjek dieksklusi karena mengalami kejadian tidak diharapkan yaitu satu subjek meninggal saat operasi (kelompok kontrol) da satu subjek dengan penundaan operasioleh dokter bedah (kelompok parasetamol). Dengan demikian, sampel penelitian ini adalah sebanyak 19 pasien dari kelompok K dan 19 pasien dari kelompok P. Pada kelompok kontrol, diperoleh subjek laki-laki berjumlah 6 orang dan subjek perempuan berjumlah 13 orang.Pada kelompok perlakuan, diperoleh 5 orang subjek laki-laki dan 14 orang subjek perempuan (Tabel 1). Rerata usia

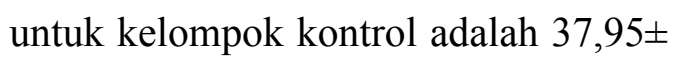
11,754 dan untuk kelompok perlakuan $42,47 \pm 12,712(p=0,262)$. Hal ini menunjukkan bahwa usia subjek penelitian diantara kedua kelompok tidak berbeda bermakna. Rerata Body Mass Index (BMI) untuk kelompok kontrol adalah 21,69 $\pm 2,532$ dan untuk kelompok perlakuan 22,58 $\pm 2,626$ (p = 0,315). Lama operasi untuk kedua kelompok tidak berbeda bermakna,

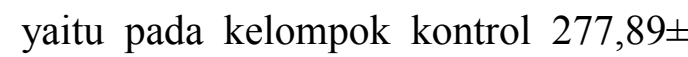
77,358 menit dan kelompok perlakuan 293,68 \pm 96,348 menit dengan $\mathrm{p}=$ 0,581 (Tabel 3). Kedua kelompok dapat dikatakan homogen.

Penilaian tingkat keparahan nyeri pasca operasi menggunakan Visual Analog Scale (VAS). Pada Tabel 4 , rerata nilai VAS 1 jam pasca operasi pada kelompok kontrol adalah 2,42 \pm 1,017 , berbeda bermakna dengan rerata nilai VAS 1 jam pasca operasi pada kelompok perlakuan, yaitu $1,11 \pm 1,243$ $(\mathrm{p}=0,002)$. VAS 6 jam pasca operasi pada kelompok kontrol 2,37 $\pm 0,761$ dan pada kelompok perlakuan 1,11 \pm 1,197 , berbeda bermakna dengan nilai $p$

Tabel 1. Karakteristik Data

\begin{tabular}{|c|c|c|c|}
\hline \multirow{2}{*}{ Variabel } & \multicolumn{2}{|c|}{ Kelompok } & \multirow{2}{*}{$\mathbf{p}$} \\
\hline & Kontrol & Perlakuan & \\
\hline \multicolumn{4}{|l|}{ Jenis kelamin } \\
\hline Laki-laki & $6(31,6 \%)$ & $5(26,3 \%)$ & $0,721^{¥}$ \\
\hline Perempuan & $13(68,4 \%)$ & $14(73,7 \%)$ & \\
\hline Umur & $37,95 \pm 11,754$ & $42,47 \pm 12,712$ & $0,262^{\alpha}$ \\
\hline BMI & $21,69 \pm 2,532$ & $22,58 \pm 2,626$ & $0,315^{\alpha}$ \\
\hline Lama operasi & $277,89 \pm 77,358$ & $293,68 \pm 96,348$ & $0,581^{\text {a }}$ \\
\hline \multicolumn{3}{|c|}{$\begin{array}{l}\text { Keterangan : } \\
{ }^{\ddagger} \text { Pearson Chi-Square Test } \\
{ }^{\natural} \text { Independent } \mathrm{t} \text {-Test }\end{array}$} & \\
\hline
\end{tabular}


$=0,001$. VAS 12 jam pasca operasi pada kelompok kontrol 1,89 $\pm 0,459$, berbeda bermakna jika dibandingkan dengan VAS 12 jam pasca operasi pada kelompok perlakuan, yaitu $1,11 \pm 1,100(\mathrm{p}=0,008)$. Setelah 24 jam pasca operasi, rerata nilai VAS pada kelompok kontrol adalah 1,95 \pm 0,524 dan pada kelompok perlakuan 1,00 $\pm 1,000$, berbeda bermakna dengan $\mathrm{p}=$ 0,001 (Tabel 2).

Intensitas nyeri pasca kraniotomi pada kelompok perlakuan lebih rendah dibanding kelompok kontrol. Nilai VAS pada kelompok perlakuan stabil diantara nilai 1 dan 1,5 dalam 24 jam pasca kraniotomi. Nilai VAS pada kelompok kontrol dalam 6 jam pasca kraniotomi sekitar 2-2,5 kemudian turun menjadi 1,5-
2 pada 12-24 jam pasca kraniotomi (Grafik 1).

Rerata total pemakaian morfin sebagai analgetik pasca operasi pada kelompok kontrol adalah 18,97 $\pm 3,946$ $\mathrm{mg}$, berbeda bermakna dibanding dengan total pemakaian morfin pada kelompok perlakuan, yaitu $11,95 \pm 5,876 \mathrm{mg}(\mathrm{p}<$ 0,001). Pemakaian morfin lebih sedikit pada kelompok perlakuan dibanding kelompok kontrol (Tabel 3).

Pada diagram batang tampak bahwa pemakaian morfin sebagai analgetik pasca kraniotomi lebih sedikit pada kelompok perlakuan dibandung kelompok kontrol dalam 24 jam pasca kraniotomi. Selisih jumlah morfin

Tabel 2. Nilai VAS 1, VAS 6, VAS 12 dan VAS 24 jam pasca operasi

\begin{tabular}{lccc}
\hline \multicolumn{1}{c}{ VAS } & Kontrol & Perlakuan & $\mathbf{p}^{\S}$ \\
\hline VAS 1 & $2,42 \pm 1,017$ & $1,11 \pm 1,243$ & 0,002 \\
\hline VAS 6 & $2,37 \pm 0,761$ & $1,11 \pm 1,197$ & 0,001 \\
\hline VAS 12 & $1,89 \pm 0,459$ & $1,11 \pm 1,100$ & 0,008 \\
\hline VAS 24 & $1,95 \pm 0,524$ & $1,00 \pm 1,000$ & 0,001 \\
\hline
\end{tabular}

Keterangan :

${ }^{\S}$ Mann-Whitney Test

Grafik 1. Nilai VAS 1, VAS 6, VAS 12 dan VAS 24 jam pasca operasi

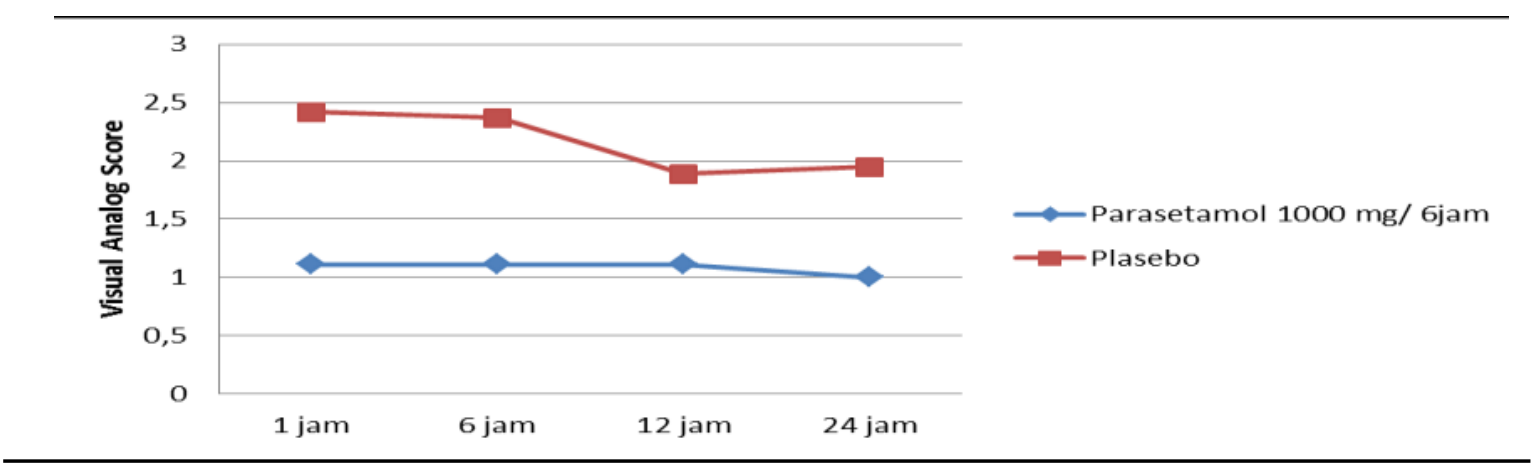


sebanyak 7,02 mg (Grafik 2)

Pada kelompok kontrol ditemukan kejadian mual pada 2 subjek dan muntah pada 2 subjek, sedangkan pada kelompok kontrol tidak ditemukan kejadian mual atau muntah (Tabel 4).

Rerata kadar substansi P sebelum operasi pada kelompok kontrol adalah 9,58 $\pm 10,656 \mathrm{pg} / \mathrm{ml}$, tidak berbeda bermakna dengan kadar substansi $\mathrm{P}$ sebelum operasi pada kelompok perlakuan, yaitu 16,89 $\pm 31,395 \mathrm{pg} / \mathrm{ml}(\mathrm{p}=$ 0,918). Hal ini menunjukkan bahwa kadar substansi P sebelum operasi pada kedua kelompok relatif sama atau homogen. Setelah 12 jam pasca operasi, rerata kadar substansi $\mathrm{P}$ pada kelompok kontrol menjadi 26,09 $\pm 22,506 \mathrm{pg} / \mathrm{ml}$, sedangkan pada kelompok perlakuan 36,58 \pm 46,960pg/ml. Pada kedua kelompok, peningkatan kadar substansi $\mathrm{P}$ setelah 12 jam pasca operasi berbeda bermakna ( $p$ $<0,001)$ (Tabel 5)

Kadar substansi P kelompok kontrol 12 jam pasca operasi meningkat sebesar $16,51 \pm 14,972 \mathrm{pg} / \mathrm{ml}$. Sedangkan pada kelompok perlakuan, peningkatannya sebesar $19,69 \pm 28,625$ pg/ml. Kedua peningkatan ini tidak berbeda bermakna dengan $\mathrm{p}=0,540$ (Tabel 6).

Pada penelitian ini, pemberian parasetamol intravena perioperatif memberikan tingkat analgesia yang

Tabel 3. Pemakaian analgetik morfin saat pasca operasi

\begin{tabular}{lcc}
\hline \multicolumn{1}{c}{ Kelompok } & Morfin & $\mathbf{p}^{\S}$ \\
\cline { 1 - 2 } Kontrol & $18,97 \pm 3,946$ & $<0,001$ \\
\hline Perlakuan & $11,95 \pm 5,876$ & \\
\hline
\end{tabular}

Keterangan :

${ }^{\S}$ Mann-Whitney Test

Grafik 2. Pemakaian morfin pasca operasi

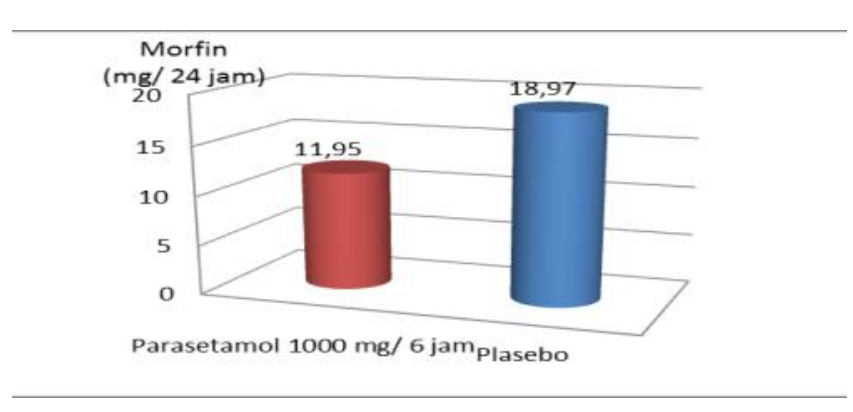


lebih baik dibanding dengan kontrol.Intensitas nyeri dalam 24 jam setelah operasi (dinilai dengan VAS pada jam 1, 6, 12 dan 24 pascaoperasi) lebih rendah dengan pemberian parasetamol dibanding tanpa pemberian parasetamol. Hal ini dikarenakan onset analgesik parasetamol tercapai dalam waktu singkat dalam 5-10 menit setelah pemberian intravena.Efek analgesik puncak tercapai dalam waktu 1 jam dan bertahan selama 4-6 jam. ${ }^{8}$

Nyeri pasca bedah, khususnya pada operasi kraniotomi paling sering terjadi dalam 48 jam setelah operasi, terutama setelah 12 jam pasca operasi. ${ }^{2}$ Dengan pemberian parasetamol perioperatif, nyeri akut ini dapat tertangani. Hal ini sesuai dengan penelitian Savvina et al. yang menyebutkan bahwa pemberian parasetamol sebagai analgesia preemptif pada pasien pediatrik yang menjalani bedah saraf memberikan analgesia pasca operasi yang adekuat, dimana nilai VAS pasca operasi $0-2$ atau tidak nyeri. ${ }^{9}$ Wininger et al. juga menyebutkan bahwa pemberian parasetamol intravena juga mengurangi nyeri dalam 24 jam pasca operasi pada operasi bedah laparoskopi abdomen. ${ }^{10}$
Durasi analgesia juga menjadi lebih lama dan waktu pemberian analgetik rescue pertama juga tertunda lebih lama dengan pemberian parasetamol intravena. $^{11}$

Efek analgesia parasetamol kemungkinan melalui beberapa cara yaitu: menghambat sintesis prostaglandin di sistem saraf pusat (aksi sentral), memblok timbulnya impuls nyeri di perifer, memperkuat jalur desendens penghambat nyeri serotonergik, inhibisi produksi nitric oxide (NO) dan hiperalgesia yang diinduksi N-methyl-D-aspartate (NMDA) atau substansi $\mathrm{P}$, dan berperan pada jalur endokanabinoid dan opioid. ${ }^{12}$ $-15$

Pemakaian morfin sebagai analgesia pasca kraniotomi berkurang sebesar $37 \%$ pada penelitian ini. Hal ini sesuai dengan penelitian Remy et al. yang menyebutkan bahwa parasetamol memiliki opioid sparing effect, dimana pada bedah mayor yang memerlukan morfin sebagai analgesia pasca operasi, kebutuhan morfin berkurang 20\%. ${ }^{12}$ Nour AA juga menyebutkan bahwa parasetamol intravena mengurangi konsumsi Patient Controlled Analgesia (PCA) morfin 
Tabel 4. Kejadian mual muntah pasca operasi

\begin{tabular}{lcc}
\hline \multicolumn{1}{c}{ Kelompok } & Mual & Muntah \\
\hline Kontrol & 2 & 2 \\
\hline Perlakuan & 0 & 0 \\
\hline
\end{tabular}

Tabel 5. Kadar Substansi P sebelum dan 12 jam setelah operasi

\begin{tabular}{lccc}
\hline \multicolumn{1}{c}{ Kelompok } & SP pre & SP post & p (berpasangan) \\
\hline Kontrol & $9,58 \pm 10,656$ & $26,09 \pm 22,506$ & $<0,001^{\dagger}$ \\
\hline Perlakuan & $16,89 \pm 31,395$ & $36,58 \pm 46,960$ & $<0,001^{\dagger}$ \\
\hline p (tidak berpasangan) & $0,918^{\S}$ & $0,793^{\S}$ & \\
\hline
\end{tabular}

Keterangan :

$\S$ Mann-Whitney Test

${ }^{\dagger}$ Wilcoxon Test

Tabel 6. Peningkatan kadar substansi P setelah 12 jam pasca operasi

\begin{tabular}{lcc}
\hline \multicolumn{1}{c}{ Kelompok } & Selisih SP & $\mathbf{p}^{\S}$ \\
\hline Kontrol & $16,51 \pm 14,972$ & \multirow{2}{*}{0,540} \\
\hline Perlakuan & $19,69 \pm 28,625$ & \\
\hline
\end{tabular}

Keterangan :

$\S$ Mann-Whitney Test

hingga $30 \%$ pada pasien yang adanya input dari nosiseptor dapat menjalani abdomenoplasti ${ }^{16}$ dan $33 \%$ berkurang dan mencegah terjadinya pada pasien bedah orthopedi mayor. ${ }^{11}$ proses hipersensitivitas yang Efek opioid sparing dikarenakan menyebabkan nyeri akut berkembang pemberian parasetamol secara preemptif analgesia, yaitu diberikan Bertolini et al. menemukan sejak sebelum ada rangsang nyeri adanya kesamaan antara parasetamol karena insisi bedah, kemudian dan kanabinoid. Parasetamol seperti dilanjutkan pemberiannya dengan halnya kanabinoid diduga memiliki interval tertentu selama dan setelah efek antinosisepsi melalui jalur operasi. Dengan metode pemberian serotoninergik desendens di spinal, seperti ini, maka proses nyeri karena terutama melalui reseptor CB1. 
Antinosisepsi yang diinduksi kanabinoid tergantung pada pelepasan peptida opioid dan interaksinya dengan reseptor $\mu$ di otak dan $\kappa$ di spinal. ${ }^{15}$ Kemungkinan mekanisme ini yang menyebabkan parasetamol mampu mengurangi dosis morfin sebagai analgetik pasca operasi pada penelitian ini.

Dengan berkurangnya jumlah pemakaian morfin pasca operasi, dapat mengurangi efek samping terkait opioid seperti mual muntah. Pada penelitian ini ditemukan efek samping berupa mual muntah pada kelompok yang tidak mendapat parasetamol intravena.

Penelitian Maund E et al menunjukkan bahwa parasetamol dapat mengurangi kejadian mual muntah karena morfin pada bedah mayor, namun tidak signifikan. ${ }^{19}$

$$
\text { Pada penelitian ini,kadar }
$$

substansi P sebelum dan setelah operasi relatif sama antara kelompok parasetamol dan plasebo. Selisih peningkatan kadar substansi $\mathrm{P}$ juga tidak berbeda bermakna antara kelompok parasetamol dan plasebo. Kadar substansi P pasca operasi sedikit lebih tinggi pada kelompok parasetamol kemungkinan karena lama operasi pada kelompok parasetamol lebih lama sekitar 15,79 menit dibanding plasebo. Durasi trauma atau stress operasi mempengaruhi kadar substansi P dalam darah. Panjang insisi kulit juga mempengaruhi kadar substansi $\mathrm{P}$ karena derajat trauma menjadi lebih tinggi. Hal ini sesuai dengan penelitian Papp Aet al, yang menyebutkan bahwa pelepasan substansi P terjadi saat trauma jaringan dan peningkatannya berhubungan dengan lama dan besar kecilnya tingkat trauma. $^{20}$

Penghambatan peningkatan kadar substansi P kemungkinan karena efek parasetamol untuk mencegah hiperalgesia di sentral maupun sensitisasi di perifer. Substansi P dihasilkan baik di sentral maupun perifer oleh neuron sensorik. ${ }^{21,22}$ Substansi P menurunkan ambang batas nosiseptif dan meningkatkan eksitabilitas membran saraf, sehingga menimbulkan hiperalgesia dan allodinia. Parasetamol menghambat jalur L-arginine-nitric oxide (NO) di sentral. Jalur ini memproduksi NO yang terkait erat dengan NMDA dan substansi P. ${ }^{23}$

Penelitian ini menggunakan dosis parasetamol $4000 \mathrm{mg} /$ hari, tidak melebihi dosis toksik yang 
direkomendasikan. ${ }^{24,25}$

Parasetamol memberikan efek menghambat hanya hiperalgesia sentral pada dosis $25 \mathrm{mg} / \mathrm{kgBB}$, dan menghambat hiperalgesia baik sentral maupun perifer pada dosis $50-100 \mathrm{mg} /$ kgBB. ${ }^{26}$ Kemungkinan hal ini juga yang menyebabkan selisih peningkatan kadar substansi P serum tidak berbeda bermakna antara kelompok kontrol dan perlakuan. Untuk menghambat hiperalgesia memerlukan dosis yang besar dan dikhawatirkan melebihi dosis yang direkomendasikan pada manusia.

\section{SIMPULAN}

Pemberian parasetamol intravena perioperatif tidak terbukti menurunkan kadar substansi $\mathrm{P}$ serum pada pasien kraniotomi dan tidak terbukti menghambat peningkatan kadar substansi P serum pada pasien kraniotomi. Akan tetapi, pemberian parasetamol intravena perioperatif mengurangi intensitas nyeri pasca kraniotomi yang ditunjukkan dengan nilai VAS yang lebih rendah dan mengurangi kebutuhan morfin sebagai analgesia pasca kraniotomi serta mengurangi kejadian mual muntah sebagai efek samping terkait morfin.

\section{DAFTAR PUSTAKA}

1. De Benedittis G, Lorenzetti A, Migliore M, Spagnoli D, Tiberio F, Villai RM. Postoperative Pain In Neurosurgery: A Pilot Study In Brain Surgery. Neurosurg 1996; 38: 466-70

2. Quiney N, Cooper R, Stoneham M, Walters F. Pain After Craniotomy. A Time For Reappraisal? $\mathrm{Br} \quad \mathrm{J}$ Neurosurg 1996; 10: 295-299

3. Kidd BL, Urban LA. Mechanisms Of Inflammatory Pain. $\mathrm{Br} \quad \mathrm{J}$ Anaesth 2001; 87(1): 3-11

4. Dunbar PJ, Visco E, Lam AM. Craniotomy Procedures Are Associated With Less Analgesic Requirements Than Other Surgical Procedures. Anesth Analg 1999;88:335-40

5. Sinatra RS, Jahr JS. Multimodal Management Of Acute Pain: The Role Of IV NSAIDS. Special Report. Anesthesiology News June $2011 ; 1-8$

6. Bujalska M. Effects Of Nitric Oxide Synthase Inhibition On Antinociceptive Action Of Different Doses Of Acetaminophen. Polish J Pharma 2004;56:605-10

7. Maund E, Mcdaid C, Rice S, Wright K, Jenkins B, Woolacott N. Paracetamol And Selective And Non-Selective Non-Steroidal Anti-Inflammatory Drugs For The Reduction In MorphineRelated Side-Effects After Major 
Surgery: A Systematic Review. Br J Anaesth 2011; 106 (3): 2927

8. Duggan ST And Scott LJ. Intravenous Paracetamol (Acetaminophen).Drugs 2009;69:101-13

9. Savvina IA, Lebedeva AO, Driagina NV. Preemptive Analgesia with Paracetamol in Pediatric Neurosurgical Patients. Anesteziol Reanimatol 2010; 1: 4 $-6$

10. Wininger SJ, Miller $\mathrm{H}$, Minkowitz HS, Royal MA, Ang RY, Breitmeyer JB, et al. A randomized, double-blind, placebo-controlled, multicenter, repeat-dose study of two intravenous acetaminophen dosing regimens for the treatment of pain after abdominal laparoscopic surgery. Clinical Therapeutics 2010; 32(14): 234869

11. Sinatra RS, Jahr JS, Reynolds LW, Viscusi ER, Groudine SB, Payen-Champenois C. Efficacy and safety of single and repeated administration of 1 gram intravenous acetaminophen injection (paracetamol) for pain management after major orthopedic surgery. Anesthesiology 2005;102(4): 822 $-31$

12. Aronoff DM, Oates JA, Boutaud O. New Insights Into The Mechanism of Action Of
Acetaminophen: Its Clinical Pharmacologic Characteristics Reflect Its Inhibition Of The Two Prostaglandin H2 Synthases. Clin Pharmacol Ther. 2006 Jan;79 (1):9-19

13. Smith HS. Potential Analgesic Mechanisms Of Acetaminophen. Pain Physician 2009; 12:269-280

14. Malaise O, Bruyere O, Reginster JY. Intravenous Paracetamol: A Review Of Efficacy And Safety In Therapeutic Use. Future Neurology 2007; 22 (6): 673-88

15. Bertolini A, Ferrari A, Ottani A, Guerzoni S, Tacchi R, Leone S. Paracetamol: New Vistas Of An Old Drug. CNS Drug Reviews 2006; 12 ( 3-4): 250-75

16. Nour AA. Study Of The Effect Of Paracetamol In Reducing Postoperative Morphine Consumption By PatientControlled Analgesia After Abdomenoplasty. Alexandria Journal of Anesthesia and Intensive Care 2006; 9(3): 44-48

17. Gottschalk A, Smith DS. New concepts in acute pain therapy: preemptive analgesia. Am Fam Physician 2001; 63(10): 1979-84

18. Woolf CK, Chong MS. Preemptive analgesia-treating postoperative pain by preventing the establishment of central sensitization. Anesth Analg 1993; 77(2): 362-367 
19. Maund E, McDaid C, Rice S, Wright K, Jenkins B, Woolacott N. Paracetamol and selective and non-selective non-steroidal antiinflammatory drugs for the reduction in morphine-related side-effects after major surgery:a systematic review. Br J Anaesth 2011; 106 (3): 292-7

20. Papp A, Valtonen P. Tissue substance $P$ levels in acute experimental burns. Burns 2006; 32: $842-5$

21. Substance P. Wikipedia [internet]. 2013 May 8 [cited 2013 June 16]. Available from: http://en.wikipedia.org/wiki/

Substance_P

22. Harrison S, Geppeti P. Substance P. Int J Biochem Cell Biol 2001; 33: $555-76$

23. Mattia C, Coluzzi F. What Anesthesiologists Should Know About Paracetamol (Acetaminophen). Minerva Anesth 2009; 75(11): 644-53
24. OFIRMEV (acetaminophen) injection prescribing information. San Diego, CA: Cadence Pharmaceuticals, Inc.; November 2010. http://www.ofirmev.com/ pdf/OFIRMEV

PrescribingInformation.pdf.

Diakses 20 Juni 2013

25. U.S. Food and Drug Administration. Acetaminophen overdose and liver injurybackground and options for reducing injury; 22 Mei 2009. http://www.fda.gov/ohrms/ dockets/ac/09/briefing/2009 4429b1-01-FDA.pdf. Diakses 20 Juni 2013

26. Bianchi M, Panerai AE. The dose -related effects of paracetamol on hyperalgesia and nociception in the rat. Br J Pharmacol 1996; 117: $130-32$ 